\title{
Fruit thinning in seven tomato varieties (Lycopersicon esculentum Mill.) under greenhouse
}

\section{Raleo de fruto en siete variedades de jitomate (Lycopersicon esculentum Mill.) bajo invernadero}

\author{
VARGAS-ESPINOZA, Everardo†, GAYTÁN-RUELAS, Marina, RIVERA-ARREDONDO, Marisa \\ and CALDERÓN-RUIZ, Alberto
}

Universidad Tecnológica del Suroeste de Guanajuato, Carretera Valle-Huanímaro km 1.2. Valle de Santiago, Guanajuato. CP. 38400

ID $1^{\text {st }}$ Author: Everardo, Vargas-Espinoza / ORC ID: 0000-0002-1238-7981, CVU CONACYT ID: 384590
ID $1^{\text {st }}$ Coauthor: Marina, Gaytán-Ruelas / ORC ID: 0000-0002-9714-7628, CVU CONACYT ID: 343244
ID $2^{\text {nd }}$ Coauthor: Marisa, Rivera-Arredondo / ORC ID: 0000-0001-5306-2027, CVU CONACYT ID: 388201
ID $3^{\text {rd }}$ Coauthor: Alberto, Calderón-Ruiz / ORC ID: 0000-0002-1721-2953, CVU CONACYT ID: 167136

DOI: $10.35429 /$ JNAS.2019.19.6.13.17

Received June 25, 2019; Accepted December 30, 2019

\begin{abstract}
The experiment was conducted from May to August 2018 at the Technological University of the Southwest of Guanajuato (UTSOE) in a randomized complete block design with three repetitions, in greenhouse 1 of $700 \mathrm{~m} 2$ of the Sustainable and Protected Agriculture Career; with the purpose of evaluating the effect of three levels of thinning of fruits, with four, five fruits and without thinning, in the yield and plant variables in seven varieties of saladette tomato produced under greenhouse and in hydroponic substrate. The varieties evaluated were: Natalie, USATX 12227, USATX 9934, Juan Pablo, USATX 24019, USATX 16117, USATX 15538, all established at a density of 31,250 plants per hectare. The thinning levels of four and five fruits per cluster had a positive influence on tomato yield, on treatments without thinning, the Natalie and Juan Pablo varieties being the ones with the highest yield, after three weeks of harvest. Regarding the number of leaves, despite finding statistical differences $(p \leq 0.01)$, the thinning of fruits did not necessarily influence the development of leaves, but rather was due to the genetics of each variety, the USATX 24019 variety being the that more leaves developed.
\end{abstract}

Lycopersicon esculentum, Thinning of fruits, Yield

\begin{abstract}
Resumen
El experimento se realizó de mayo a agosto del 2018 en la Universidad Tecnológica del Suroeste de Guanajuato (UTSOE) en un diseño en bloques completos al azar con tres repeticiones, en el invernadero 1 de $700 \mathrm{~m} 2$ de la Carrera de Agricultura Sustentable y Protegida; con la finalidad de evaluar el efecto de tres niveles de raleo de frutos, a cuatro, cinco frutos y sin raleo, en el rendimiento y variables de planta en siete variedades de jitomate saladette producidas bajo invernadero y en sustrato hidropónico. Las variedades evaluadas fueron: Natalie, USATX 12227, USATX 9934, Juan Pablo, USATX 24019, USATX 16117, USATX 15538, todas establecidas a una densidad de 31,250 plantas por hectárea. Los niveles de raleo de cuatro y cinco frutos por racimo influyeron de manera positiva en el rendimiento de jitomate, sobre los tratamientos sin raleo, siendo las variedades Natalie y Juan Pablo las que mayor rendimiento presentaron, luego de tres semanas de cosecha. En cuanto al número de hojas, a pesar de encontrar diferencias estadísticas $(p \leq 0.01)$, el raleo de frutos no necesariamente influyó en el desarrollo de hojas, sino más bien se debió a la genética de cada variedad, siendo la variedad USATX 24019 la que mayor número de hojas desarrolló.
\end{abstract}

Lycopersicon esculentum, Raleo de frutos, Rendimiento

Citacion: VARGAS-ESPINOZA, Everardo, GAYTÁN-RUELAS, Marina, RIVERA-ARREDONDO, Marisa and CALDERÓN-RUIZ, Alberto. Fruit thinning in seven tomato varieties (Lycopersicon esculentum Mill.) under greenhouse. Journal of Natural and Agricultural Sciences. 2019, 6-19: 13-17

\footnotetext{
*Correspondence to Author (evargase@utsoe.edu.mx)

$\dagger$ Researcher contributing first author.
} 


\section{Introduction}

Recently, tomato production has increased by about 50 percent, driven by a larger agricultural area, with protected farming systems. Tomato availability is available in all months of the year (SRE, 2015). Mexico is the main exporter of fresh tomatoes worldwide, with about $20 \%$ of the volume and $25 \%$ of the value traded, which are mainly destined for the US. The country exports around 1.5 million tons per year, which represents between 50 and $70 \%$ of the production volume. In Mexico, about 52,374.91 ha of tomato are sown, with an average yield of 56.42 t.ha-1, making it the second most important vegetable in terms of planted area, the most transcendent in terms of volume in the national market and first for its production value (SIAP-SAGARPA, 2018).

In order to seek the transfer of technology to small producers; It was decided to implement the present project to evaluate the effect of thinning of fruits with three levels of thinning, in the yield and yield components in seven varieties of tomato type saladete, under greenhouse conditions and hydroponic substrate, to compare and determine the best treatment after three weeks of harvest after two months after transplantation.

\section{Literature review}

The expression of the crop yield potential depends on both its genetic constitution and environmental factors (climate, soil), biological factors and production technique (Sánchez and Escalante, 1988). Pruning, understood as the removal of parts of the plant (buds, developed shoots, roots or fruits), serves to maintain an adequate form and growth, as long as it is done without affecting the development of the plant (Halfacre, 1979).

The importance of pruning lies in the fact that sometimes a rapid growth of some organ can compete with the leaves for nutrients that can easily be translocated, which causes foliar senescence and a reduction in its photosynthetic capacity. There is also competition between the bodies whose growth and development are simultaneous; such is the case of apex growth with floral differentiation, a process that occurs at a very early age in many plants.
The resulting growth of a pruning is quite fast because the root / aerial part relationship is temporarily altered. In addition, the removal of foliage and branches reduces the amount of stored carbohydrates and, more importantly, reduces the leaf area available for production (Salisbury and Ross, 1994).

Sánchez et al., (2005), mention that the decrease in the leaf area index allows an increase in the average weight of the fruits, but reduces the yield per unit area and the thinning of fruits induces an increase in the weight of the fruits. fruits in clusters but yield per unit area decreases.

According to Velasco et al., (2011), to achieve fruit quality, evaluated as the optimum development of the fruits and their uniformity, it is highly recommended to eliminate one, two or more fruits per cluster, depending on the number of fruits tied (usually those at the end of the cluster, since these usually tend to be smaller and have little commercial value).

In addition, the size that the fruits reach is influenced by the amount of photoassimilates available per plant, since by eliminating flowers, the photoassimilates are distributed among less fruits and a larger size is promoted that helps partially compensate for the loss of yield per unit area caused by the lower number of fruits per plant or per cluster (Wolf and Rudich, 1988; Shishido et al., 1989).

The removal of small fruits can be done manually or with scissors, immediately after mooring or at the latest when the fruits are the size of a marble. Occasionally, thinning of small fruits in the clusters is also justified when symptoms of calcium deficiency occur in the fruits (Velasco et al., 2011).

The essential thing about thinning is to look for an increase in the caliber of the fruit and the formation of yolks, but in turn you can obtain a number of other benefits, such as; a better color, a higher sugar content, a better sanitary control, and among others (Salisbury and Ross, 1994). 
However, it is important to point out that special care should be taken in the pollination and efficiency practices of the same, since it depends on the fact that fruits with sufficient seeds originate, being responsible for the growth and development of the pulp and fruit itself. If there is no optimal pollination or fertilization, production decreases, hence its importance (Velasco et al., (2011).

On the other hand, and being equally important in this process, the nutritional balance plays a fundamental role to take into account from transplantation to the productive stage of the crop (León, 2006). Within the nutrition of the tomato crop, balanced growth, flowering and fruiting or fruit filling solutions can be made and applied, based on an optimum $\mathrm{pH}$ of 5.5 to 5.8 and a maximum electrical conductivity of 3.5 dS. $\mathrm{m}^{-1}$.

\section{Materials and methods}

\section{Project localization}

The present work was carried out from May to August 2018 at the Technological University of the Southwest of Guanajuato (UTSOE) in the $700 \mathrm{~m} 2$ greenhouse 1 of the Sustainable and Protected Agriculture Race, located on the Valle-Huanímaro Highway Km. 1.2 in Valle from Santiago, Gto., Mexico.

\section{Plant material and planting density}

Seven varieties of saladette tomatoes from the USAgriseeds commercial house were established in the greenhouse. The varieties evaluated were: Natalie, USATX 12227, USATX 9934, Juan Pablo, USATX 24019, USATX 16117, USATX 15538, all established at a density of 31,250 plants per hectare.

\section{Experimental design and data analysis}

The experiment was established based on a randomized complete block design with three repetitions. A total of 21 treatments were evaluated, consisting of the combination of the seven tomato varieties with three levels of thinning (4 and 5 fruits per bunch and without thinning). The experimental unit for each treatment was made up of three pots with river sand, each with a plant and a single stem.
The data were analyzed using the SAS ${ }^{\circledR}$ statistical package version 9.3 to carry out the analysis of variance (ANOVA), a correlation between the evaluated variables and the Tukey means comparison test $(\mathrm{p} \leq 0.05)$.

\section{Evaluated variables}

Yield (kg / plant): It was obtained through the harvest of clusters in commercial maturity and weighed with the help of a digital analytical balance, obtaining a cumulative at the end of three weeks of harvest, from 3 months after transplant.

Apex diameter (mm): It was obtained with the help of a digital vernier, measuring above the last well-formed leaf for three weeks to finally obtain an average.

Plant height (m): It was obtained by measuring from the base of the stem to the apex with the help of a flexometer, the accumulated growth after three months after the transplant.

Number of leaves: The total of wellformed leaves was counted after three months after transplantation.

\section{Agronomic management}

Tutoreo of the plant was carried out starting at two weeks after the transplant, in addition to pruning leaves and axillary shoots weekly. Pollinations were done every day manually and with air. The lowering of the plant began once the plants reached two meters high.

As for the thinning of fruits, this work began when the first clusters of fruits appeared in the "marble" stage and as they appeared and developed consecutively on the plant.

Irrigation and crop nutrition were managed based on Steiner's solution taking an electrical conductivity that was $2.5 \mathrm{dS} / \mathrm{m}$ from the transplant stage, up to $3.0 \mathrm{dS} / \mathrm{m}$ at the production stage, with a $\mathrm{pH}$ of 5 to 6 , with fertilizer sources of macro and chemical micronutrients. Biweekly applications of amino acids, growth hormones and chelated micronutrients were also made. 
The management of pests and diseases was carried out weekly or biweekly, beginning with periodic monitoring, implementation of cultural work and through the application of biological products based on fungi and bacteria, organic products based on botanical extracts, sulfur and copper, and low toxicological chemical pesticides.

\section{Results}

In the analysis of variance for the variables of performance and components thereof (Table 1), highly significant differences $(p \leq 0.01)$ were detected in the different treatments for the variables of number of leaves and yield, which can be attributed to the different tomato varieties expressed their genetic potential differently as they were improved.

\begin{tabular}{|l|r|r|r|r|}
\multicolumn{1}{|c}{ SV } & \multicolumn{1}{c|}{ AD } & \multicolumn{1}{c|}{ AP } & \multicolumn{1}{c|}{ NOL } & \multicolumn{1}{c|}{ PFM } \\
\hline Treatment & 0.906 & 0.064 & $25.348^{* *}$ & $0.043^{* *}$ \\
\hline Error & 0.379 & 0.055 & 6.26 & 0.015 \\
\hline CV (\%) & 12.43 & 9.74 & 9.01 & 15.92 \\
\hline Half & 4.94 & 2.4 & 27.76 & 0.79 \\
\hline
\end{tabular}

SV: Source of variation; Treatment: Treatment; CV: Coefficient of variation; AD: Apex diameter; AP: Plant height; NOL: Number of sheets; PFM: Performance. ** Highly significant with $\mathrm{p} \leq 0.01$.

Table 1 Mean squares and level of statistical significance for the yield and plant variables in the fruit thinning experiment in seven tomato varieties under greenhouse. Santiago Valley, Gto. 2018

The coefficients of variation in the four variables evaluated were less than $16 \%$, indicating that the data have reliability. The Tukey mean comparison test $(p \leq 0.01)$ in Table 2 , in which it was ordered based on the variable yield from highest to lowest; For this same variable, it was found that the Natalie varieties with 5 fruits per cluster, as well as Juan Pablo, grated with 4 fruits per cluster, behaved as the most productive after three weeks of harvest, exceeding 900 grams per plant. This means that the two levels of thinning evaluated, in themselves had no direct effect on the yield after three weeks of harvest, but rather was the effect of the genetics of each variety. These two varieties stand out from the others and coincide in that they were among the first that the company improved and brought to the market, by continuing to recommend and produce them today, especially for restrictive production conditions.
As for the variable number of leaves, the USATX 24019 variety thinned to both four and five fruits per bunch, behaved as the most vigorous in foliage (31.8 leaves), however this vigor had no direct effect on yield, due to to which it was the one that had less performance, below 600 grams; however, it would be possible to be evaluated with more number of cuts to be able to attribute or not a direct effect of greater leaf development with the yield. It should be noted that varieties with a lot of foliage should be managed in plantation, tutoreo and appropriate pruning frames, to guarantee ventilation between the vegetal canopy, lower incidence of diseases and better effect of foliar applications.

\begin{tabular}{|c|c|c|c|c|}
\hline $\begin{array}{l}\text { Treatment } \\
\text { (variety) }\end{array}$ & $\begin{array}{c}\text { Yield } \\
\text { (kg / } \\
\text { plant) }\end{array}$ & $\begin{array}{l}\text { Number } \\
\text { of leaves }\end{array}$ & $\begin{array}{c}\text { Apex } \\
\text { diameter } \\
(\mathrm{mm})\end{array}$ & $\begin{array}{l}\text { Plant } \\
\text { height } \\
\text { (m) }\end{array}$ \\
\hline Natalie 5F & $0.973 \mathrm{a}$ & $26.5 \mathrm{abc}$ & $4.9 \mathrm{a}$ & $2.19 \mathrm{a}$ \\
\hline Juan Pablo 4F & $0.967 \mathrm{a}$ & $25.5 \mathrm{abc}$ & $4.8 \mathrm{a}$ & $2.18 \mathrm{a}$ \\
\hline Juan Pablo 5F & $0.953 \mathrm{ab}$ & $30.4 \mathrm{ab}$ & $4.1 \mathrm{a}$ & $2.11 \mathrm{a}$ \\
\hline USATX $161175 \mathrm{~F}$ & $0.917 \mathrm{ab}$ & $27.7 \mathrm{ab}$ & $5.4 \mathrm{a}$ & $2.52 \mathrm{a}$ \\
\hline USATX 9934 5F & $0.905 \mathrm{ab}$ & $25.0 \mathrm{abc}$ & $5.5 \mathrm{a}$ & $2.41 \mathrm{a}$ \\
\hline USATX 9934 SR & $0.858 \mathrm{ab}$ & $26.1 \mathrm{abc}$ & $4.0 \mathrm{a}$ & $2.37 \mathrm{a}$ \\
\hline USATX 15538 SR & $0.857 \mathrm{ab}$ & $19.9 \mathrm{c}$ & $3.9 \mathrm{a}$ & $2.29 \mathrm{a}$ \\
\hline USATX 16117 4F & $0.853 \mathrm{ab}$ & $26 a b c$ & $5.0 \mathrm{a}$ & $2.45 \mathrm{a}$ \\
\hline Natalie SR & $0.832 \mathrm{ab}$ & $28.1 \mathrm{ab}$ & $5.5 \mathrm{a}$ & $2.52 \mathrm{a}$ \\
\hline USATX 9934 4F & $0.816 \mathrm{ab}$ & $26.1 \mathrm{abc}$ & $4.5 \mathrm{a}$ & $2.50 \mathrm{a}$ \\
\hline Juan Pablo SR & $0.799 \mathrm{ab}$ & $29.8 \mathrm{ab}$ & $4.3 \mathrm{a}$ & $2.31 \mathrm{a}$ \\
\hline USATX 12227 SR & $0.779 \mathrm{ab}$ & $30.5 \mathrm{ab}$ & $4.7 \mathrm{a}$ & $2.23 \mathrm{a}$ \\
\hline Natalie 4F & $0.778 \mathrm{ab}$ & $23.6 \mathrm{bc}$ & $4.9 \mathrm{a}$ & $2.28 \mathrm{a}$ \\
\hline USATX $122275 \mathrm{~F}$ & $0.771 \mathrm{ab}$ & $27.7 \mathrm{ab}$ & $5.3 \mathrm{a}$ & $2.48 \mathrm{a}$ \\
\hline USATX 15538 4F & $0.737 \mathrm{ab}$ & $28.4 \mathrm{ab}$ & $5.3 \mathrm{a}$ & $2.27 \mathrm{a}$ \\
\hline USATX 16117 SR & $0.730 \mathrm{ab}$ & $28.0 \mathrm{ab}$ & $4.4 \mathrm{a}$ & $2.39 \mathrm{a}$ \\
\hline USATX 12227 4F & $0.719 \mathrm{ab}$ & $28.7 \mathrm{ab}$ & $4.6 \mathrm{a}$ & $2.25 \mathrm{a}$ \\
\hline USATX $155385 \mathrm{~F}$ & $0.654 \mathrm{ab}$ & $30.5 \mathrm{ab}$ & $5.7 \mathrm{a}$ & $2.51 \mathrm{a}$ \\
\hline USATX $240195 \mathrm{~F}$ & $0.599 \mathrm{ab}$ & $31.8 \mathrm{a}$ & $5.6 \mathrm{a}$ & $2.76 \mathrm{a}$ \\
\hline USATX 24019 SR & $0.588 \mathrm{ab}$ & $30.0 \mathrm{ab}$ & $5.1 \mathrm{a}$ & $2.45 \mathrm{a}$ \\
\hline USATX $240194 \mathrm{~F}$ & $0.569 \mathrm{~b}$ & $31.8 \mathrm{a}$ & $5.3 \mathrm{a}$ & $2.60 \mathrm{a}$ \\
\hline Mean & 0.79 & 27.76 & 4.94 & 2.4 \\
\hline DSM & 0.393 & 7.802 & 1.919 & 0.731 \\
\hline
\end{tabular}

F: fruits; SR: no thinning; DSM: Minimum significant difference; Are means with equal letters within the same column statistically equal (Tukey $\alpha \leq 0.05$ ).

Table 2 Comparison of means for the yield and plant variables, in the fruit thinning experiment in seven tomato varieties under greenhouse. Santiago Valley, Gto. 2018

In the correlation test (Table 3), the experiment showed highly positive or direct correlation $(p \leq 0.01)$ between the plant height with the apex diameter and the number of leaves; which supposes that the varieties not only had a good height development but also developed vigorous apices; and in terms of the number of leaves, the higher the height of the plant allowed a greater number of knots and consequently a greater number of leaves, responding to the genetics of the variety. 
On the other hand, regarding the negative correlations $(p \leq 0.01)$ between the number of leaves with the yield, the analysis indicates that some varieties can yield the same or more than the others, once they adapt to the production conditions and that can express their maximum genetic potential for production, even if they do not develop many leaves; and that in general, these varieties are compact with short internodes, suitable for production in low greenhouses, macro-tunnels or in the open field where the tutore system is complicated a little more than in protected conditions.

\begin{tabular}{|l|l|l|l|}
\hline & \multicolumn{1}{|c}{ AD } & \multicolumn{1}{c|}{ AP } & \multicolumn{1}{c|}{ NOL } \\
\hline AP & $0.357 * *$ & & \\
\hline NOL & $0.292^{*}$ & $0.511^{* *}$ & \\
\hline PFM & -0.179 & -0.281 & $-0.379 * *$ \\
\hline
\end{tabular}

AD: Apex diameter; AP: Plant height; NOL: Number of sheets; PFM: Performance. *: Significant with $\alpha \leq 0.05$; $* *$ : Significant with $\alpha \leq 0.01$.

Table 3 Correlation coefficients between the variables evaluated in the fruit thinning experiment in seven tomato varieties under greenhouse. Santiago Valley, Gto. 2018

\section{Conclusions}

The thinning levels of four and five fruits per cluster had a positive influence on tomato yield, on treatments without thinning, with Natalie and Juan Pablo varieties having the highest yield, after three weeks of harvest.

Regarding the number of leaves, despite finding statistical differences, the thinning of fruits did not necessarily influence the development of leaves, but rather was due to the genetics of each variety, with the USATX 24019 variety being the one with the highest number of leaves development.

The thinning levels evaluated had no effect on the apex diameter and plant height, responding to each variety expressing its genetic potential naturally despite the elimination of fruits.

It is pertinent to evaluate a greater number of weeks of harvest to observe the behavior of other varieties that are recommended as yielding in other management and production conditions.

\section{References}

Halfacre G., R. 1979. Horticultura. AGT Editor, S.A. México, D.F. 727 p.

León, G. H.M. 2006. Guía para el cultivo de tomate en invernadero. Segunda edición. Editorial SEP-INDAUTOR. 263 p. Chihuahua, Chih.

Salisbury B., F.; C. W. Ross. 1994. Fisiología Vegetal. Editorial Iberoamericana.

México. $759 \mathrm{p}$.

Sánchez Del C., F.; E. Escalante, R. 1988. Hidroponía. Tercera edición. Universidad Autónoma Chapingo. Chapingo, México. Pp. 17 y 18.

Sánchez, Del C.; Ucan, Ch. I.; Contreras, M. E.; Corona S. T. 2005. Efecto de la densidad de población y raleo de frutos sobre el rendimiento y tamaño del fruto en tomate. Revista Fitotecnia Mexicana. Vol. 28 (1): 33 - 38.

Secretaría de Relacione Exteriores. 2015. México: Primer Exportador Mundial de Tomate. Recuperado de: http://consulmex.sre.gob.mx/omaha/images/JIT OMATE/jitomate.pdf

SIAP-SAGARPA. 2018. Producción agrícola por cultivo.

http://infosiap.siap.gob.mx/aagricola_siap/iculti vo/index.jsp

Shishido, Y, N; Seyama, S; Imada, Y Hori. 1989. Carbon budget in tomato plants as affected by night temperature evaluated by steady state feeding with $14 \mathrm{CO}_{2}$. Ann. Bot. 63:357-367.

Velasco, H. E.; Nieto, A. R.; Navarro, L. E. 2011. Cultivo del tomate en hidroponía e invernadero. Ed. BBA. México, D.F. 125 p.

Wolf, S.; J. Rudich. 1988. The growth rates of fruits on different parts of the tomato plants and the effect of water stress on dry weight accumulation. Sci. Hort. 34:1-11. 